Abstracta Iranica Iranica

Revue bibliographique pour le domaine irano-aryen

Volume 40-41 | 2019

Comptes rendus des publications de 2017-2018

\title{
Kavita Singh. Real birds in Imaginary Landscapes. Mughal Painting between Persia and Europe
}

\section{Iván Szántó}

\section{Q OpenEdition \\ 1 Journals}

\section{Electronic version}

URL: http://journals.openedition.org/abstractairanica/49526

DOI: 10.4000/abstractairanica.49526

ISBN: 1961-960X

ISSN: 1961-960X

Publisher:

CNRS (UMR 7528 Mondes iraniens et indiens), Éditions de l'IFRI

Electronic reference

Iván Szántó, "Kavita Singh. Real birds in Imaginary Landscapes. Mughal Painting between Persia and Europe", Abstracta Iranica [Online], Volume 40-41 | 2019, document 1, Online since 30 October 2019, connection on 17 April 2021. URL: http://journals.openedition.org/abstractairanica/49526 ; DOI: https://doi.org/10.4000/abstractairanica.49526

This text was automatically generated on 17 April 2021.

Tous droits réservés 


\title{
Kavita Singh. Real birds in Imaginary Landscapes. Mughal Painting between Persia and Europe
}

\author{
Iván Szántó
}

\section{REFERENCES}

Kavita Singh. Real birds in Imaginary Landscapes. Mughal Painting between Persia and Europe. Los Angeles: Getty Research Institute, 2017, 107 p., 30 colour illustrations, ISBN 9781606065181

1 This small volume contains the published version of the author's lecture in the New Research in Art History series of the Getty Research Institute, Los Angeles, which was delivered under the title Looking East, Looking West: Mughal Painting Between Persia and Europe, on 19 November, 2015.

2 According to Singh, hybridity in Mughal painting should not be dismissed as eclecticism or strangeness, for it is a consciously employed device. For instance, when one half of a late-Mughal painting, Lovers and Musician in Landscape (by Mīr Kalān Khān, ca.1775, Lucknow, now Copenhagen, David Collection), vests the musician with European-inspired three-dymensionality but the other half keeps the lovers in the twodimensionality of the Persian tradition, they bring two separate worlds into a single picture. By rendering the lovers differently from the rest of the composition, the painting conjures up poetry itself, depicting the couple as the musician's subject. Singh compares the bringing of the teller into the tale with a technique common also in IndoPersian poetry whereby the narrator names himself at the end of his poem, abstracting his vivid narration into a text and making a distinction between "real" and "fabled" realities.

3 The author acknowledges that Amy Landau, Ebba Koch, Yael Rice, and other scholars have already shown that much of the arbitrary-looking devices are not signs of 
clumsiness but are demonstrations of visual knowledge and that these optical effects are employed for persuasion. Thus, instead of summarising the results of previous research, Singh introduces a series of case-studies in the form of careful readings of individual paintings. The starting point is the arrival of Safavid artists to India accompanying emperor Humayun on his return from exile in 1555. From this starting point, we follow the delopment of Mughal painting through its indigenisation during the reign of Bābar, the appearance and uses of European elements during Akbar, and the synthesis under Jahāngir. To conclude the volume, Singh links the phenomenon of multiple styles on the same page with philosophical debates about the nature of reality and illusion. Frequent references on the "opposing twins", Mānī and Bihzād, in these debates and in art are suggestive of the two skills that a Mughal artist had to master and demonstrate, often on the same sheet. These two skills, illusion and allusion, were represented respectively by Europeanising opticalism embedded in a Persianate deep structure.

\section{AUTHORS}

\section{IVÁN SZÁNTÓ}

Eötvös Loránd University, Budapest \& Austrian Academy of Sciences, Vienne 